\title{
INFLUENCE OF TREASURY SINGLE ACCOUNT ON FINANCIAL MANAGEMENT IN FEDERAL UNIVERSITIES IN NORTH-EAST, NIGERIA
}

\author{
JOSEPH, R. I., ADAMU I., \& HARUNA, A. \\ Department of Vocational and Technology Education \\ Faculty of Technology Education \\ Abubakar Tafawa Balewa University Bauchi, Nigeria \\ https://doi.org/10.37602/IJSSMR.2020.3305
}

\begin{abstract}
The study was on the influence of treasury single account on financial management in federal universities in north-east, Nigeria. Four objectives, four research questions and four null hypotheses guided the study. The design for the study was a descriptive survey. The population of the study was 368 staff and the Total Sample Technique was employed for the study. The instrument for data collection was adapted 4-point rating scale questionnaire. The instrument was validated by experts and pilot tested with 40 staff from the university of Jos. A reliability coefficient of 0.88 was obtained. Data were collected by the researcher assisted by 3 research assistants. The data collected were coded into the Statistical Package for Social Science (SPSS, 23). The package was used to run mean scores and standard deviation to answer the research questions while the hypotheses were tested using linear regression analysis at the 0.05 level of significance. The results revealed that treasury single account has a significant influence on internally generated revenue, financial accountability; financial transparency and controlling of fraud and fraudulent practices in Federal Universities in North-East, Nigeria. It was concluded that the introduction of treasury single account will help to address the problem of mismanagement embezzlement and lack of accountability of public fund in public universities in North-east, Nigeria. It was recommended among others that the federal government should formulate appropriate sanctions to where there is any financial irregularity.
\end{abstract}

Keywords: Treasury, Single, Account, Financial, Management, Universities

\subsection{INTRODUCTION}

The existence of corruption in the Nigerian system generally has been a challenge for achieving the objective of the universities. As a result of this, tertiary educational institutions strive for efficiency and transparency in their services, operations and finances which brought about a growing interest among these institutions to enhance risk management through their processes and procedures so as to promote efficient services among professionals within the institutions. The most common measure over these processes and/or procedures is the treasury single account (Ochai, \& Ogwa, 2018; Akosile, \& Fasesin, 2013). Treasury single account is one of the several devices adopted by the Federal Republic of Nigeria to 


\section{International Journal of Social Sciences and Management Review}

checkmate the problem of corrupt practices, miss-appropriation and accountability in fiscal operations in the public sector including universities in Nigeria. Oti, Igbeng and Obim (2016) define Treasury single account as a financial policy, which requires all Ministries, Departments and Federal agencies to move their deposits with the commercial banks into a single account with the Central Bank of Nigeria (CBN).

The purpose is primarily to ensure accountability of government revenue, enhance transparency and avoid misapplication of public funds. The maintenance of a Treasury single account is hope to ensure proper financial management by eliminating idle funds usually left with different commercial banks and in a way to enhance reconciliation of revenue collection and payment (Adeolu, 2015). Consequently, in September 2015, President Buhari administration ordered all Federal Ministries, Departments and Agencies, Federal universities inclusive to withdraw their account balances (cash deposit) with commercial Banks outside and within Nigeria.

Despite the laudable objectives of the TSA, the study conducted by Ochai and Adikwu, (2018) reported that available fund in universities seems to be grossly managed to be specific. Fraudulent practices, misappropriation of fund and lack of accountability is common in universities in north-east Nigeria The Academic Staff Union of Universities (ASUU) has criticized President Muhammadu Buhari's Treasury Single Account (TSA) policy, barely a month after the Academic Staff Union of Polytechnics (ASUP) expressed similar concerns in 2015. According to ASUU, the TSA could constitute bottlenecks in the smooth running of the Nigerian University System if hurriedly implemented. Similarly, in mid-September, ASUP National President, Comrade Chibuzo Asomugha, had advised Buhari to provide special consideration for educational institutions in the country as regards the TSA (Bashir, 2016). Base on these, the study determined the influence of treasury single account on (i) internally generated revenue; (ii) financial accountability; (iii) financial transparency; and (iii) controlling of fraud and fraudulent practices in federal universities in North-East, Nigeria.

\subsection{RESEARCH QUESTIONS}

The following research questions were formulated to guide this study:

1. What is the influence of treasury single account on internally generated revenue in Federal Universities in North-East, Nigeria?

2. What is the influence of treasury single account on financial accountability in Federal Universities in North-East, Nigeria?

3. What is the influence of treasury single account on financial transparency in Federal Universities in North-East, Nigeria?

4. What is the influence of treasury single account on controlling of fraud and fraudulent practices in Federal Universities in North-East, Nigeria?

\subsection{RESEARCH HYPOTHESES}

The following null hypotheses were tested at $5 \%$ level of significance: 


\section{International Journal of Social Sciences and Management Review}

H01: Treasury single account has no significant influence on internally generated revenue in Federal Universities in North-East, Nigeria.

H02: Treasury single account has no significant influence on financial accountability in Federal Universities in North-East, Nigeria.

H03: Treasury single account has no significant influence on financial transparency in Federal Universities in North-East, Nigeria.

H04: Treasury single account has no significant influence on controlling fraud and fraudulent practices in Federal Universities in North-East, Nigeria.

\subsection{RESEARCH METHODOLOGY}

This study adopted a descriptive survey design. A descriptive research design is concerned with finding out what, where and how of a phenomenon (Cooper, \& Schinder, 2006). Descriptive studies are non-experimental researches that describe the characteristics of a particular individual, or of a group. The design was adopted in this study because it enabled the researcher to collect information on respondents' habits, thoughts and opinions from the population of the study by use of questionnaires.

The population of the study comprised of 368 staff, which comprised of 49 management staff, 213 accounting staff and 106 internal audit staff of seven (7) Federal universities in North-East, Nigeria. The total population and sample were used in this study because the population is small and can be managed. This agreed with the submission of Cresswell (2011) who opined that the entire population can be used if it is manageable.

The instrument for data collection was structured questionnaires with close-ended items on a numerical scale of strongly agree 4 points to strongly disagree 1 point. The questionnaire was adapted from Radzi, Ghani, and Siraj (2015) and Sulaimon (2017). The validity of the instrument was determined by experts in accounting, audition and business education. Their corrections were incorporated into the final copy. The reliability of the instrument was determined at the University of Jos, Plateau State. Forty (40) staff were used for the pilot study. The result was used to determine the reliability of the instrument using Cronbach alpha. A reliability coefficient of 0.88 was obtained.

The researcher and research assistant collected the data using the direct contact approach. The method helped in building a rapport and social relationship with the respondents. The face-toface methods also motivate the respondents to trust the source and to get down straight to answering the questionnaire. The data collected from the study were fed into the Statistical Package for Social Science (SPSS, 23) for easy analysis and explanation of results. Descriptive statistics were used to answer the research questions using interval scale as decision rule while the hypotheses were tested using linear regression analysis at 0.05 (i.e. $5 \%$ level of significance) when the $\mathrm{p}$-value is $\leq 0.05$, the null hypothesis was rejected while alternative hypothesis was accepted and when the p-value was $>0.05$, the null hypothesis was accepted while alternative hypothesis was rejected.

\subsection{Research Question One}




\section{International Journal of Social Sciences and Management Review}

Volume: 03, Issue: 03 "May - June 2020"

ISSN 2582-0176

What is the influence of treasury single account on internally generated revenue in Federal Universities in North-East, Nigeria?

The analysis of the 10 items used to address research question one revealed the mean scores ranged 2.52 to 3.25 with standard deviations of 0.63 and 0.81 respectively. The weighted mean scores obtained were under the index score of agreed. This is also obtainable in the grand mean of 2.95 which indicated that respondents agreed with the items on the influence of treasury single account on internally generated revenue in Federal Universities in NorthEast, Nigeria,

Table 1: Descriptive statistics used to determine the influence of treasury single account on internally generated revenue in Federal Universities in North-East, Nigeria

\begin{tabular}{llll}
\hline QI. & Statement & Mean & Std. dev. Remark \\
\hline
\end{tabular}

1. There has been an improvement in the financial status of federal universities.

2. Government policies on TSA have adversely affected the availability of fund to federal universities.

3. Federal universities generate more revenue to government treasury as a result of effective TSA.

4. There has been a high increase in revenue generation in the universities due to effective control measures.

5. TSA has helped improve the revenue generation in federal universities.

6. The subsidy or grant generated from donor agencies for training of graduates is a source of revenue generation for the University.

7. Money generated from the registration in training programmes is a source of revenue to the University.

8. Online and internet registration charges of the University boost the University IGR account.

$3.13 \quad 0.78 \quad$ Agree

9. Universities generate high revenue from space and shop rentals.

10. Payment for transcripts boost the internally generated revenue of universities 


\section{International Journal of Social Sciences and Management Review}

\subsection{Research Question Two}

What is the influence of treasury single account on financial accountability in Federal Universities in North-East, Nigeria?

The descriptive statistics used to answer research question two in Table 2 revealed the weighted mean ranged 2.90 to 3.24 which were classified under the benchmark of agreed. The grand mean score of 3.07 obtained indicated that the respondents agreed that treasury single account has an influence on financial accountability in Federal Universities in NorthEast, Nigeria

Table 2: Descriptive statistics used to determine the influence of treasury single account on financial accountability in Federal Universities in North-East, Nigeria

\begin{tabular}{|c|c|c|c|c|}
\hline QI. & Statement & Mean & Std. dev. & Remark \\
\hline 11. & $\begin{array}{l}\text { Inconsistent approaches to financial management have } \\
\text { viewed as an indication of manipulation. }\end{array}$ & 3.24 & 0.81 & Agree \\
\hline 12. & $\begin{array}{l}\text { Management can decide if the university is on target to } \\
\text { achieve its objectives within agreed times scales and } \\
\text { budget. }\end{array}$ & 3.06 & 0.76 & Agree \\
\hline 13. & $\begin{array}{l}\text { Planning is based to the management process and } \\
\text { involves looking ahead to prepare for the future. }\end{array}$ & 3.12 & 0.78 & Agree \\
\hline 14. & Universities maintain financial transaction & 2.91 & 0.73 & Agree \\
\hline 15. & Universities have accurate record-keeping systems & 3.12 & 0.78 & Agree \\
\hline 16. & $\begin{array}{l}\text { There is proper, prudent and timely documentations and } \\
\text { progress reports. }\end{array}$ & 3.09 & 0.77 & Agree \\
\hline 17. & $\begin{array}{l}\text { Responsible officials submit all statutory financial } \\
\text { returns when and where they are required in time. }\end{array}$ & 3.14 & 0.78 & Agree \\
\hline 18. & $\begin{array}{l}\text { The internal audit unit reviews process to monitor } \\
\text { whether appropriate and accurate financial information } \\
\text { is received. }\end{array}$ & 3.02 & 0.76 & Agree \\
\hline 19. & $\begin{array}{l}\text { The reporting system on organizational structures spells } \\
\text { out all the responsibilities of each section/unit in the } \\
\text { organization. }\end{array}$ & 2.90 & 0.73 & Agree \\
\hline 20. & $\begin{array}{l}\text { Management has assigned responsibilities for the timely } \\
\text { review of audit reports and resolution of any non- } \\
\text { compliance items noted in audit reports. }\end{array}$ & 3.01 & 0.75 & Agree \\
\hline & Grand mean & \multicolumn{2}{|r|}{3.07} & Agree \\
\hline
\end{tabular}

Source: Fieldwork, 2020

4.3 Research Question Three 


\section{International Journal of Social Sciences and Management Review}

Volume: 03, Issue: 03 "May - June 2020"

ISSN 2582-0176

What is the influence of treasury single account on financial transparency in Federal Universities in North-East, Nigeria?

The result presented in Table 3 was used to answer the research question three. From the Table, the minimum weighted mean score was 2.73 and the maximum was 3.23 which were found to be under the scale of agree. The grand mean score of 3.08 obtained suggested that respondents were of opinion that treasury single account has an influence on financial transparency in Federal Universities in North-East, Nigeria

Table 3: Descriptive statistics used to determine the influence of treasury single account on financial transparency in Federal Universities in North-East, Nigeria

\begin{tabular}{|c|c|c|c|c|}
\hline QI. & Statement & Mean & Std. dev. & Remark \\
\hline 21. & $\begin{array}{l}\text { Universities has principles intended to guide behavior } \\
\text { and help in the development of policies and procedures. }\end{array}$ & 2.79 & 0.70 & Agree \\
\hline 22. & $\begin{array}{l}\text { Workers in the university operate with honesty and } \\
\text { propriety. }\end{array}$ & 2.97 & 0.74 & Agree \\
\hline 23. & $\begin{array}{l}\text { The resource of the university is well coordinated to } \\
\text { ensure implementation of budgeted items. }\end{array}$ & 2.73 & 0.68 & Agree \\
\hline 24. & $\begin{array}{l}\text { The university monitoring involves comparing actual } \\
\text { performance with plans to evaluate the effectiveness of } \\
\text { plans. }\end{array}$ & 2.86 & 0.71 & Agree \\
\hline 25. & Supervision of cash receipt is carried out regularly. & 3.23 & 0.81 & Agree \\
\hline 26. & $\begin{array}{l}\text { The university has procedures in place to manage its } \\
\text { financial responsibilities. }\end{array}$ & 3.05 & 0.76 & Agree \\
\hline 27. & $\begin{array}{l}\text { Management of universities acts with a great degree of } \\
\text { integrity in execution of their roles. }\end{array}$ & 3.07 & 0.77 & Agree \\
\hline 28. & Ethical values are upheld in all management decisions. & 2.95 & 0.74 & Agree \\
\hline 29. & $\begin{array}{l}\text { Internal reviews of implementation of internal controls } \\
\text { in units are conducted periodically. }\end{array}$ & 3.00 & 0.75 & Agree \\
\hline 30. & Internal audit is independent of management influence. & 3.05 & 0.76 & Agree \\
\hline & Grand mean & \multicolumn{2}{|r|}{3.08} & Agree \\
\hline
\end{tabular}

\section{Source: Fieldwork, 2020}

\subsection{Research Question Four}

What is the influence of treasury single account on controlling of fraud and fraudulent practices in Federal Universities in North-East, Nigeria?

The analysis of 10 questionnaire items used to answer research question four in Table 4 revealed the mean scores ranged 2.90 to 3.25 with standard deviations of 0.72 and 0.81 respectively. The grand mean scores obtained was 3.04 which indicated that the respondents agreed that treasury single account has an influence on controlling of fraud and fraudulent practices in Federal Universities in North-East, Nigeria 
International Journal of Social Sciences and Management Review

Volume: 03, Issue: 03 “May - June 2020”

ISSN 2582-0176

Table 4: Descriptive statistics used to determine the influence of treasury single account on controlling of fraud and fraudulent practices in Federal Universities in North-East, Nigeria

\begin{tabular}{|c|c|c|c|c|}
\hline QI. & Statement & Mean & Std. dev. & Remark \\
\hline 31. & $\begin{array}{l}\text { There is massive reduction in the incidences of fraud } \\
\text { and fraudulent practices in federal universities due to } \\
\text { the introduction of TSA. }\end{array}$ & 2.99 & 0.75 & Agree \\
\hline 32. & $\begin{array}{l}\text { TSA has created more opportunities in aiding and } \\
\text { abetting fraud in federal universities. }\end{array}$ & 3.05 & 0.76 & Agree \\
\hline 33. & $\begin{array}{l}\text { The treasury single account will have a positive impact } \\
\text { on the salaries of staff in the federal universities. }\end{array}$ & 2.99 & 0.75 & Agree \\
\hline 34. & $\begin{array}{l}\text { There is a regular payment of staff salaries in the } \\
\text { federal universities. }\end{array}$ & 2.93 & 0.73 & Agree \\
\hline 35. & $\begin{array}{l}\text { Salary payment has not been affected by the } \\
\text { introduction of TSA. }\end{array}$ & 3.25 & 0.81 & Agree \\
\hline 36. & $\begin{array}{l}\text { Salary payment has become irregular as a result of the } \\
\text { introduction of TSA. }\end{array}$ & 2.99 & 0.75 & Agree \\
\hline 37. & $\begin{array}{l}\text { Universities have well-established whistle-blower } \\
\text { mechanisms to control fraud. }\end{array}$ & 3.21 & 0.80 & Agree \\
\hline 38. & $\begin{array}{l}\text { Universities take appropriate action in case of detected } \\
\text { fraud. }\end{array}$ & 2.90 & 0.72 & Agree \\
\hline 39. & $\begin{array}{l}\text { Risk based internal audits are carried out in universities } \\
\text { to control fraud. }\end{array}$ & 3.02 & 0.75 & Agree \\
\hline 40. & $\begin{array}{l}\text { Universities have established lines of communication } \\
\text { with policies for further investigations of detected } \\
\text { fraud. }\end{array}$ & 3.05 & 0.76 & Agree \\
\hline Gra & ad mean & & 3.04 & Agree \\
\hline
\end{tabular}

Source: Fieldwork, 2020

\subsection{TEST OF NULL HYPOTHESES}

\subsection{Test of hypothesis one}

Treasury single account has no significant influence on internally generated revenue in Federal Universities in North-East, Nigeria.

The statistical evidence documented in Table 5 reveals that the variable treasury single account had a standardized coefficients beta value of $.514, \mathrm{p}=.000$. This indicates a significant contribution of the variable in the model, that is, the treasury single account has a significant positive influence on internally generated revenue in Federal Universities in North-East, Nigeria. This result does not support the prediction of hypothesis H1 that the 


\section{International Journal of Social Sciences and Management Review}

Volume: 03, Issue: 03 "May - June 2020"

ISSN 2582-0176

treasury single account has no significant influence on internally generated revenue in Federal Universities in North-East, Nigeria. Hence, treasury single account is considered by this study as one of the determinants of internally generated revenue in Federal Universities in North-East, Nigeria.

Table 5: Regression Analysis on the influence of treasury single account on internally generated revenue in Federal Universities in North-East, Nigeria.

\begin{tabular}{ccccc}
\hline Variable & $\begin{array}{c}\text { Standardized } \\
\text { Coefficients Beta }\end{array}$ & T value & P value & Decision \\
\hline Treasury single account & .514 & 9.802 & .000 & Rejected \\
\hline Source: Fieldwork, 2020 & & & &
\end{tabular}

\subsection{Test of hypothesis Two}

Treasury single account has no significant influence on financial accountability in Federal Universities in North-East, Nigeria.

The statistical evidence documented in table 6 reveals that the treasury single account had a standardized coefficients beta value of $.549, \mathrm{p}=.000$. This indicates a significant contribution of the variable in the study, that is, treasury single account has a significant positive influence on financial accountability in Federal Universities in North-East, Nigeria. This result does not support the prediction of hypothesis $\mathrm{H} 2$ that treasury single account has no significant influence on financial accountability in Federal Universities in North-East, Nigeria. This implies that treasury single account is one of the determinants of financial accountability in Federal Universities in North-East, Nigeria.

Table 6:Regression Analysis on the influence of treasury single account on financial accountability in Federal Universities in North-East, Nigeria

\begin{tabular}{ccccc}
\hline Variable & $\begin{array}{c}\text { Standardized } \\
\text { Coefficients Beta }\end{array}$ & T value & P value & Decision \\
\hline Treasury single account & 549 & 10.386 & .000 & Rejected \\
\hline
\end{tabular}

Source: Fieldwork 2020

\subsection{Test of hypothesis Three}

Treasury single account as no significant influence on financial transparency in Federal Universities in North-East, Nigeria

Evidence from the statistical outcome documented in Table 7 indicates the influence of treasury single account on financial transparency in Federal Universities in North-East, Nigeria was positive and significant with a standardized coefficients beta value of $.502, \mathrm{p}=$ .000 . However, this result does not support the prediction of $\mathrm{H} 3$ that treasury single account has no significant influence on financial transparency in Federal Universities in North-East, Nigeria. Furthermore, the result implies that financial accountability in Federal Universities in North-East, Nigeria is also influenced by a treasury single account. 


\section{International Journal of Social Sciences and Management Review}

Volume: 03, Issue: 03 "May - June 2020"

ISSN 2582-0176

Table 7: Regression Analysis on the influence of treasury single account on financial transparency in Federal Universities in North-East, Nigeria

\begin{tabular}{lcccc}
\hline Variable & $\begin{array}{c}\text { Standardized } \\
\text { Coefficients Beta }\end{array}$ & T value & P value & Decision \\
\hline Treasury single account & .502 & 9.505 & .000 & Rejected \\
\hline
\end{tabular}

Source: Fieldwork, 2020

\subsection{Test of hypothesis Four}

Treasury single account has no significant influence on controlling fraud and fraudulent practices in Federal Universities in North-East, Nigeria.

The result of regression analysis documented in Table 8 reveals that treasury single account a standardized coefficients beta value of $.553, \mathrm{p}=.000$. The result, therefore, shows the significant influence of treasury single account on controlling of fraud and fraudulent practices. Nevertheless, this result does not support the prediction of $\mathrm{H} 4$ that Treasury single account has no significant influence on controlling fraud and fraudulent practices in Federal Universities in North-East, Nigeria. The result further implies that treasury single account is controlling of fraud and fraudulent practices in Federal Universities in North-East, Nigeria.

Table 8: Regression Analysis on the influence of treasury single account on controlling of fraud and fraudulent practices in Federal Universities in North-East, Nigeria

\begin{tabular}{ccccc}
\hline Variable & $\begin{array}{c}\text { Standardized } \\
\text { Coefficients Beta }\end{array}$ & T value & P value & Decision \\
\hline Treasury single account & .553 & 10.875 & .000 & Rejected \\
\hline
\end{tabular}

Source: Fieldwork, 2020

\subsection{DISCUSSION OF THE FINDINGS}

The result of the research question which was further affirmed by the test of corresponding null hypothesis one shows that treasury single account has a significant influence on internally generated revenue in Federal Universities in North-East, Nigeria. The result of the study agreed with the report of Yusuf (2015) who opined that treasury single account is a public accounting system under which all government revenue, receipts and income and collected into a single account, usually maintained by the country's Central Bank and all payments done through this account as well (Yusuf, 2015). Similarly, System specs (2016) which argued that treasury single account help to block most of the financial leakages that have been the bane of university financial mismanagement practices.

Similarly study conducted by Yusuf and Mohammed (2016) points that by implementing the Treasury single account, the Federal Government, through its independent revenue ecollection initiative, hope to automate and manage direct revenue collection by ministries or agencies. In fact, treasury single account is seen as a structure that unifies government bank accounts that gives an amalgamated or integrated view of government's cash resources (Yusuf \& Chiejina, 2015). Kanu (2016) opined that treasury single account as one of the 


\section{International Journal of Social Sciences and Management Review}

Volume: 03, Issue: 03 "May - June 2020"

ISSN 2582-0176

financial policies implemented by the federal government of Nigeria to integrate all revenues and treasuries from all ministries. The study of Ofurum, Oyibo and Ahuche (2018) on the extent to which Treasury Single Account has improved Federally Collected Revenue (FCR) and Gross Domestic Product (GDP) of the economy in Nigeria shows that treasury single account improves the financial management and revenue collection in Nigeria.

Research question two shows that all the items used to determine the influence of treasury single account on financial accountability in Federal Universities in North-East, Nigeria were agreed by the respondents. Test of corresponding null hypothesis two further suggested that the influence of treasury single account on financial accountability in Federal Universities in North-East, Nigeria was significant. The result was in line with the study conducted by SystemSpecs (2016) argues that through treasury single account, ministry and agencies finding it easy to explain how it has used its resources and what it has achieved as a result to all stakeholders, including beneficiaries. BAshir (2016) stated that treasury single account will help to address the cases of fraud are rampant in the Nigerian public sector, to the extent that every segment of the public service is virtually involved in this act of financial misconduct.

Oyedele (2015) pointed out that the factors hindering accountability in Nigeria include poor record-keeping system in the various public establishments, fraudulent practices owing to the existing poverty syndrome in the country, coupled with the poor value systems, poor mode of releasing funds to the public establishments, shortage of personnel and facilities in the monitoring units of the public establishments. The author added that treasury single account has the potentials of the address the problem. Nwaorgu and Ezenwaka (2017) ascertained the effect of treasury single account and accountability in the Nigeria Public Sector. The study indicated atha adaptation of a treasury single account (TSA) and accountability in the Nigeria Public Sector is capable of plugging financial loopholes, promoting transparency and accountability in Federal Health Tertiary Institutions in South-East Nigeria.

The mean score of items used to answer research question three indicated that respondents agreed with all the items used to determine the influence of treasury single account on financial transparency in Federal Universities in North-East, Nigeria. The test of corresponding null hypothesis three suggested that the influence of treasury single account on financial transparency was significant. The result of the study was in line with that of Adegite (2010) who noted that there are three pillars of accountability, which the UNDP tagged ATI (Accountability Transparency and Integrity). The study of Emme, \& Chukwurah (2015) reported that treasury single account system is a network of subsidiary accounts all linked to the main account such that, transactions are effected in the subsidiary accounts but closing balances on these subsidiary accounts are transferred to the main account, at the end of each business day. according to Ahmed (2016) treasury single account assisted in providing greater transparency in the public financial system; Assist in gaining greater clarity to national financing needs and public debt management; Increase in fiscal savings (less transaction charges, more revenue); Improving financial markets; and provision of more accurate accounting and improved reporting.

The result of research question four indicated that the respondents agreed with the items on the influence of treasury single account of controlling fraud and fraudulent practices in 


\section{International Journal of Social Sciences and Management Review}

Federal Universities in North-East, Nigeria. The test of null hypothesis four indicated that the influence of treasury single account no controlling of fraud and fraudulent practices in Federal Universities in North-East, Nigeria was significant. The result was in line with the earlier study of Singh (2009) who opined that institution must be open about its work, making information about its activities and plans available to relevant stakeholders' thorough treasury single account. Otherwise, if an organization is not transparent, then it may give the impression of having something to hide. The study of Chui (2010) also reported that treasury single account will help to solve the problem of fraud.

The study of Dycks et al., (2013) shows that fraud entails concealment, nondisclosure and misrepresentation can be curtailed through a single account. The study of Oyedele (2015) indicated that the treasury single account is a way of unifying various government's bank accounts to give a consolidated view of government cash resources. The author maintained that the system helps to reduce fraud and fraudulent activities. The CBN (2015) states that "Centralized banking is a system whereby banking arrangements of entities are integrated within a single account or set of linked accounts. This model could be referred to as the Treasury Single Account (TSA) for the purpose of enhancing cash management and reduce embezzlement of public funds. The study of Akujuru and Enyioko (2017) on the effects of treasury single account policy on corruption in Nigeria from 2011 to 2017 shows that treasury single account (TSA) block financial leakages, reduce corruption, promote transparency and prevent mismanagement of government's revenue in public sector organisations.

\subsection{CONCLUSION}

The results of the study show that treasury single account has a positive influence on internally generated revenue, financial accountability; financial transparency and controlling of fraud and fraudulent practices in Federal Universities in North-East, Nigeria, it, therefore, means that the introduction of TSA has gone a long way to block the identified financial leakages in revenue generation and promote transparency and accountability in the federal universities in North-east, Nigeria. It was concluded that the introduction of treasury single account will help to address the problem of mismanagement embezzlement and lack of accountability of public fund in public universities in North-east, Nigeria. Consequently, the TSA will help the federal government to know the cash flow in the universities in north-east, Nigeria at any given time without any interference.

\subsection{RECOMMENDATIONS}

Based on the findings of the study, the following recommendations were made:

1. The federal government should formulate appropriate sanctions to where there is any financial irregularity.

2. The federal government through NUC should help to ensure, anything that will block proper implementation of TSA which will affect transparency; limpidity and accountability of public fund in federal universities in northeast Nigeria are eliminated. 


\section{International Journal of Social Sciences and Management Review}

Volume: 03, Issue: 03 “May - June 2020”

ISSN 2582-0176

3. The federal government should monitor and evaluate the extent of implementation of the TSA policy in all the federal universities in north-east Nigeria to ensure complete adoption and implementation of the policy in all the universities in the zone.

4. The federal government should initiate policies and various measures to make sure that proper accounting of the funds into the Treasury Single Account follows due process and any subsequent foul play by any federal universities in north-east Nigeria.

\section{REFERENCES}

Adegite, E.O (2010). Accounting Accountability and Nation Development. Nigeri Accountant,

Adeolu, I. A. (2015). Understanding the treasury single Account (TSA) system-things you should know. Business \& Economy, Market Development, 2(3), 14-25.

Ahmed, A. (2016). The treasury single account (TSA) as an instrument of financial prudence and management: Prospects and problems. Research Journal of Finance and Accounting, 7(4), 18-36.

Akosile, A. I., \& Fasesin, O. O. (2013). A comparative assessment of internal control system in public and private universities in South-West, Nigeria. Research Journal of Finance and Accounting, 4(13), 25-33.

Akujuru, C., \& Enyioko, N. (2017). Effects of Treasury Single Account Policy on Corruption in Nigeria. Retrieved October 15, 2019 from: from SSRN: https://ssrn.com/abstract=2940695

Bashir, T. M. (2016). Effects of Treasury Single Account on Public Finance Management in Nigeria. Research Journal of Finance and Accounting Vol 7. No 6. Page 164-166.

CBN (2015). Revised guidelines for compliance with TSA by banks in Nigeria. Retrieved from www.cbn.gov.ng (Accessed November 15, 2019).

Chui, L. (2010). An experetienal examination of the effects of fraud specialst and audit mindset on fraud risk assessments on the development of fraud-related problems representations. Unpublished $\mathrm{PhD}$ thesis. University of North Texas.

Creswell, J. W. (2011). Research design: Qualitative, quantitative and mixed research approaches (4th ed.). Washington DC: Sage Publications.

Daily Trust Editorial, (2015). Buhari on Treasury Single Account, Vanguard, August 28, P6.

Dyck, A., Morse, A. \& Zingales, L. 2013. How pervasive is corporate fraud. Available at http://ssrn.com/abstract=2222608 (accessed 05/03/19). 


\section{International Journal of Social Sciences and Management Review}

Volume: 03, Issue: 03 "May - June 2020"

ISSN 2582-0176

Emme, O.I. \& Chukwurah, D. C. (2015): Analysis of Pros and Cons of Treasury Single Account Policy in Nigeria. Arabian journal of business and management review (OMAN chapter), 5(4), 20.

Kanu C. (2016). Impact of Treasury Single Account on the Liquidity. ABC Journal of Advanced Research, 5, 43-52.

Nwaorgu, I., \& Ezenwaka, F. (2017). Treasury Single Accounting (TSA) and Public Sector Accountability in Nigeria. Journal of Economics, Management and Trade, 19(4), 1-8.

Ochai, G.O., \& Ogwa, A.V.O. (2018). Influence of Treasury Single Account on the Management of Universities in North Central Nigeria: Implication for Counseling. IOSR Journal of Humanities And Social Science (IOSR-JHSS) 23(3) 66-72.

Ofurum, C. N., Oyibo, P. C., \& Ahuche, Q. E. (2018). Impact of Treasury Single Account on Government Revenue and Economic Growth in Nigeria: A Pre-Post Design. International Journal of Academic Research in Business and Social Sciences, 8(5), 283-292.

Oti, O, Igbang, I. \& Obim, O. (2016). The concept of treasury single account. Retrieved July 5, 2019 from www.concept-treasurysingleaccount.com.org.

Oyedele, T. (2015). Treasury Single Account Implications. Retrieved from: https://www.linkedin.com/pulse/treasury-singleaccount-implications-taiwo-oyedele. $08 / 02 / 2019$

Radzi, N. M., Ghani, M. F. A., \& Siraj, S. (2015). Development of an effective school-based financial management profile in Malaysia: The Delphi method application. Educational Research and Reviews, 10(12), 1679-1694.

Sulaimon, B.A. (2017). Effect of treasury single account (TSA) on some selected federal parastatals in Kano metropolis. A Seminar paper presented at the Department of Accounting Bayero University, Kano.

SystemSpecs (2016). Understanding the treasury single account system. www.systeSpace.com. Retrieved November 18, 2019.

Yusuf I. A. (2015). Counting Cost of Treasury Single Account. Available atwww.thenationonlineng.net/counting-cost-of-treasury-single: The Nation Newspaper, Retrieved on 23/10/ 2019.

Yusuf, A. \& Chiejina, N. (2015). Anti-graft war: One economy, one account. Sunday Nation, August, 16

Yusuf, A., \& Mohammed, B. (2016). Effects of Treasury Single Account on Public Finance Management in Nigeria. Research Journal of Finance and Accounting, 7(6), 164-170. 